\title{
Erythrocyte Count
}

National Cancer Institute

\section{Source}

National Cancer Institute. Erythrocyte Count. NCI Thesaurus. Code C51946.

The determination of the number of erythrocytes in a blood sample. 